\title{
Influence of the impregnation with boron compounds on the physical properties of Eucalyptus wood
}

\author{
Influência da impregnação com compostos de boro nas propriedades físicas \\ da madeira de eucalipto
}

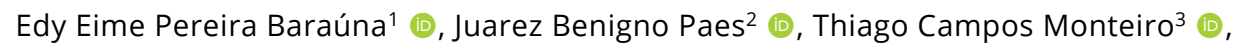
Jordão Cabral Moulin² (1), Gabriella Leite Ferreira ${ }^{4}$ (1), Amanda Grassmann Silveira ${ }^{5}$ (1), Talita Baldin $^{5}$ (D), Carlos Roberto Sette Junior ${ }^{6}$ (D), Marina Donária Chaves Arantes ${ }^{7}$ (1)

${ }^{1}$ Universidade Federal de Minas Gerais - UFMG, Motes Claros, MG, Brasil

${ }^{2}$ Universidade Federal do Espírito Santo - UFES, Jerônimo Monteiro, ES, Brasil

${ }^{3}$ Universidade Federal do Paraná - UFPR, Curitiba, PR, Brasil

${ }^{4}$ Faculdade Santo Agostinho - FASA, Motes Claros, MG, Brasil

${ }^{5}$ Universidade Federal de Santa Maria - UFSM, Santa Maria, RS, Brasil

'Universidade Federal de Goiás - UFG, Goiânia, GO, Brasil

${ }^{7}$ Universidade Federal de São João Del Rei - UFSJ, Sete Lagoas, MG, Brasil

\begin{abstract}
How to cite: Baraúna, E. E. P., Paes, J. B., Monteiro, T. C., Moulin, J. C., Ferreira, G. L., Silveira, A. G., Baldin, T., Sette Junior, C. R., \& Arantes, M. D. C. (2020). Influence of impregnation with boron compounds in the physical properties of Eucalyptus wood . Scientia Forestalis, 48(128), e3383. https://doi.org/10.18671/scifor.v48n128.09
\end{abstract}

\begin{abstract}
The aim of this study was to evaluate the effect of boron compounds utilized in wood impregnation, its influence on the physical properties of eucalyptus wood and to verify the veracity of the equilibrium moisture content obtained by the Simpson's equation. The wood impregnation consisted of $4 \%$ and $8 \%$ of boron compound concentrations and was applied to the wood of three Eucalyptus clones. To analyze the equilibrium moisture content, the test samples were acclimatized at different temperatures and relative humidity. The dry density, shrinkage, and anisotropy coefficient for all the wood samples were measured. The presence of the boron compound in impregnated wood enhanced the dry density and radial shrinkage in one of the Eucalyptus clones. The equilibrium moisture content dropped when the $4 \%$ boron compound concentration was used to impregnate the wood. The Simpson's equation must be applied with caution for ascertaining the equilibrium moisture content measurements because different values are achieved when compared with the findings of the acclimatized chambers.
\end{abstract}

Keywords: Wood impregnation; Boric acid; Equilibrium moisture content; Density; Shrinkage.

\section{Resumo}

O objetivo deste estudo foi avaliar o efeito dos compostos de boro utilizados na impregnação, sua influência sobre as propriedades físicas da madeira de eucalipto e verificar a veracidade do teor de umidade de equilíbrio obtido pela equação de Simpson. A impregnação consistiu da aplicação de soluções de 4 e $8 \%$ de concentração de compostos de boro na madeira de três clones de eucalipto. Para analisar o conteúdo de umidade de equilíbrio da madeira, as amostras foram aclimatadas em diferentes temperaturas e umidades relativas. A densidade anidra, contração e coeficiente de anisotropia para todas as amostras de madeira foram determinados. A presença de composto de boro na madeira impregnada incrementou a densidade anidra e o inchamento radial para todos os clones de eucalipto testados. O teor de umidade de equilíbrio diminuiu quando a concentração de $4 \%$ de compostos de boro foi usada. A equação de Simpson deve ser aplicada com cautela para verificar as medições de conteúdo de umidade de equilíbrio, uma vez que valores diferentes são obtidos quando comparados aos da câmara climatizada.

Palavras-chave: Impregnação da madeira; Ácido bórico; Teor de umidade de equilíbrio; Densidade; Inchamento.

Financial support: None.

Conflict of interest: Nothing to declare.

Corresponding author: jbp2@uol.com.br

Received: 22 May 2019.

Accepted: 22 October 2019

Editor: Paulo Henrique Müller Silva.

(c) This is an Open Access article distributed under the terms of the Creative Commons Attribution License, which permits unrestricted use, distribution, and reproduction in any medium, provided the original work is properly cited. 


\section{INTRODUCTION}

Wood treatment is a set of preventive and curative measures against xylophagous agents, which degrade wood and feed on the natural polymers of the cell wall. Using a variety of methods, chemical preservatives are introduced to restrict these actions in the wood (Tascioglu et al., 2013). A major concern in using chemical preservatives is that they are often toxic to all biota and the environment, which ultimately puts restrictions on their usage (Singh \& Singh, 2012). To circumvent these disadvantages, the chemical properties of these compounds have been examined (Davidson et al., 2016). With their unique characteristics, boron compounds are a good option as a feasible alternative for its use in wood treatment.

Boron compounds are a commonly available soil micronutrient, and borates naturally occur in most superficial waters. Borates are useful for wood treatment because they have essential and desirable characteristics, including toxicity to xylophagous organisms, and they are more environmentally friendly than other substances such as arsenic compounds; and they are not toxic to both humans and domestic animals. Borates are not volatile; they are odorless, water soluble, and durable. They make wood less susceptible to fire and do not change the natural wood color (Mohareb et al., 2010).

Among the boron compounds designated for wood treatment, boric acid and borax mixed with boric acid are the most conventional for wood treatments (Kartal et al., 2007; Lepage et al., 2017), also often used for treatment of wood veneers (Colakoglu et al., 2003; Willerding \& Vianez, 2003), plywood (Lahiry, 2005; Özçifçi, 2008), and bamboo strips (Xu et al., 2013; Rosa et al., 2014, 2016).

However, one disadvantage is the tendency to be easily leached by water, which limits their use as wood treatment, especially when they are in contact with environments high in moisture or in soil contact (Obanda et al., 2008; Caldeira, 2010). Several studies have been conducted to minimize the boron compounds leaching effects (Kartal et al., 2004; Lyon et al., 2007; Zou et al., 2018). These studies attempted to reduce boron solubility by adding different chemical compounds to produce an insoluble complex, while other studies employed water repellent compounds (Lesar et al., 2009; Mourant et al., 2009; Zou et al., 2018).

Chemical compounds utilized as wood treatment to increase the wood durability can induce changes in the wood properties, specifically the physical properties. This study aimed to evaluate the effect of boron compounds utilized in wood impregnation, their influence on the physical properties of eucalyptus wood and to verify the veracity of the equilibrium moisture content obtained by the Simpson's equation.

\section{MATERIAL AND METHODS}

\section{Wood samples}

Wood samples were obtained from three 4-year-old Eucalyptus clones (named clones A, $B$, and C); taken from a plantation site in the Bocaiúva region, coordinate -16.618940 latitude and -44.042204 longitude, Minas Gerais State, Brazil. In Brazil eucalyptus wood from trees aged between 4 and 5 years is used in materials such as fence posts (Torres et al., 2011), small posts for transmission of electric power in rural areas and pallets.

For each clone, six trees have been evaluated, and from each one of them, a wooden disc was removed from the basal region. From that disc three wood samples with dimensions of $2.0 \times 2.5 \times 5.0 \mathrm{~cm}$ (radial $\times$ tangential $\times$ longitudinal) from the sapwood region were obtained, totalizing 54 test samples. Only sapwood was used, because it is a permeable wood, and the objective of study was to evaluate the effect of impregnation on its dimensional stability.

\section{Preparation of solutions and impregnation of samples}

Boric acid (95\%, pure for analysis, PA) and sodium tetraborate (borax, 95\%, PA) were used to prepare the solutions. These solutions were composed by equal parts of a dry mixture of the reagents in two different concentrations ( 4 and $8 \%$ ). 
Three different treatments consisting of $4 \% ; 8 \%$, and control (non-impregnated wood) were analyzed. Each treatment involved 18 test samples with six replications by clone, totaling 54 test samples.

Impregnating the solutions into the wood was performed according to the American Wood Protection Association - AWPA E10-12 (American Wood Protection Association, 2014). The wood samples were packed into a desiccator and subjected to an initial vacuum of 660 $\mathrm{mm} \mathrm{Hg} \mathrm{(26} \mathrm{in} \mathrm{Hg),} \mathrm{to} \mathrm{withdraw} \mathrm{air} \mathrm{from} \mathrm{the} \mathrm{interior} \mathrm{of} \mathrm{the} \mathrm{samples.} \mathrm{The} \mathrm{solution} \mathrm{contained} \mathrm{in}$ the volumetric flask was released, and then two more vacuum applications of 25 min duration each one were performed for the maximum impregnation of the material, with a 40-min interval between them. The impregnation procedure was performed for both concentrations ( 4 and $8 \%$ ), using approximately $1.5 \mathrm{~L}$ of the treatment solution. After the impregnation, the wood samples were wrapped in a polyethylene filter for 14 days to enhance the impregnation and fixation of the solution, and later weighed.

To determinate the equilibrium moisture content, an acclimatization chamber was used, in which the wood samples were conditioned for simulations under conditions of different temperatures and relative humidity - RH (Table 1).

Table 1. Temperature and relative humidity in the acclimatization chamber.

\begin{tabular}{cc}
\hline Temperature $\left({ }^{\circ} \mathbf{C}\right)$ & Relative humidity (\%) \\
\hline 18 & 57 \\
18 & 59 \\
18 & 67 \\
30 & 57 \\
30 & 59 \\
30 & 67 \\
\hline
\end{tabular}

The wood samples, which were placed inside the acclimatization chamber under the conditions proposed, were periodically (every 3 days) removed to measure their mass until mass stabilization was achieved. When the masses of the samples stabilized at the given temperatures and relative humidity, the equilibrium moisture content was measured. Once all mass measurements were taken, the samples were completely oven dried at $103 \pm 2^{\circ} \mathrm{C}$ and the equilibrium moisture content was calculated for each pre-established condition using Equation 1 (Skaar, 1988).

$\mathrm{EMC}=\frac{\mathrm{SM}-\mathrm{DM}}{\mathrm{SM}} \times 100$

Where - EMC: equilibrium moisture content (\%); SM: stabilized mass of the wood sample (g) inside the acclimatized chamber; DM: dry mass of the wood sample (g).

The estimated equilibrium moisture content was calculated by Equation 2, proposed by Simpson (1971), employing the same pre-established conditions of the acclimatization chamber.

$\mathrm{EMC}=\left[\frac{\mathrm{K}_{1} \mathrm{~K}_{2} \mathrm{~h}}{1+\mathrm{K}_{1} \mathrm{~K}_{2} \mathrm{~h}}+\frac{\mathrm{K}_{2} \mathrm{~h}}{1-\mathrm{K}_{2} \mathrm{~h}}\right] \frac{1800}{\mathrm{~W}}$

Where - $\mathrm{K}_{1}: 4.737+(0.04773 \times \mathrm{T})-\left(0.00050123 \times \mathrm{T}^{2}\right) ; \mathrm{K}_{2}: 0.705941+(0.001698 \times \mathrm{T})-$ $\left(0.000005553 \times \mathrm{T}^{2}\right) ; \mathrm{W}: 223.384+(06942 \times \mathrm{T})+\left(0.0185324 \times \mathrm{T}^{2}\right) ; \mathrm{T}$ : temperature $\left({ }^{\circ} \mathrm{C}\right) ; \mathrm{h}$ : relative water vapor pressure.

The dry density of the wood samples was obtained by dividing the mass and respective volume of the completely dried samples. Radial and tangential wood shrinkages of the 
samples were measured according to the International Organization for Standardization- ISO 4469-1981 (International Organization for Standardization, 1981), while the volumetric shrinkage was determined according to ISO 4858-1982 (International Organization for Standardization, 1982). The coefficient of anisotropy was obtained by the relationship of the tangential and radial shrinkages.

A completely randomized statistic design was applied and a variance analysis was performed to compare the effect of environmental conditions (temperature and $\mathrm{RH}$ ), and treatment (control, 4 and 8\%) for each Eucalyptus clone. When the F test was significant ( $p<$ $0.05)$, the Tukey test was applied $(p<0.05)$ to compare the means of equilibrium moisture contents, dry density, shrinkages, and coefficient of anisotropy. Previous to the variance analyses, the Bartlett test (to verify the normality of the data distribution) and Cochran test (to the homogeneity of variances) were performed.

\section{RESULTS AND DISCUSSION}

Impregnated wood samples of the three Eucalyptus clones at both boron compound concentrations revealed significant differences in the equilibrium moisture content when they were submitted to distinct temperature and $\mathrm{RH}$. In Figure 1 the significant differences between the treatments of the wood in each condition that the wood was submitted can be seen; as well as the values estimated by Simpson's equation (1971).

Means followed by the same letter within each condition (temperature $x$ relative humidity), do not differ (Tukey, $p>0.05$ ). The equilibrium moisture content obtained by Simpson's equation is represented by the perpendicular line drawn to the direction of the bars.
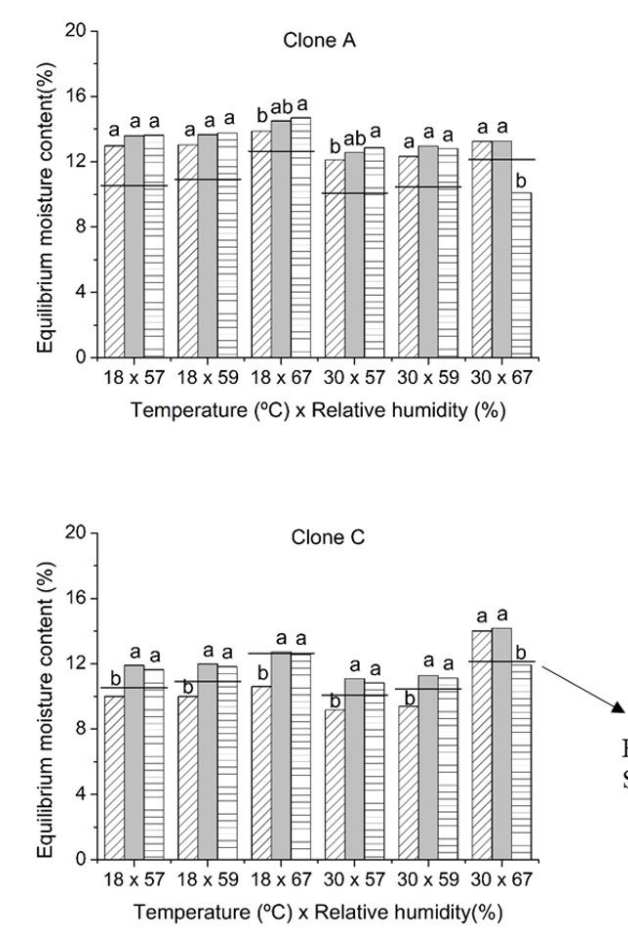

Figure 1. Mean values for the equilibrium moisture content of the wood samples from the three Eucalyptus clones for impregnated wood ( 4 and $8 \%$ concentrations of boron compound) and control.

The clones presented different responses to treatments, temperature and relative humidity ratios. Clone $A$ presented a significant difference in the relations $18 \times 67 ; 30 \times 57$ and $30 \times 67$, while clones $B$ and $C$ showed interference of the treatments in all combinations of temperature and humidity. It is important to emphasize that the temperature of $30^{\circ} \mathrm{C}$ and at 
$67 \%$ relative humidity gave the same responses in the three evaluated clones, where the control presented lower equilibrium moisture than the treatments with the preservative.

In general, the $4 \%$ boron treatment had the lowest equilibrium moisture values. In most cases, the Simpson's equation underestimated the equilibrium moisture results, but for clone $C$, at most equilibrium moisture ratios with the $4 \%$ treatment, it was still lower than that estimated by the Simpson's equation. The $8 \%$ treatment was the one that most conserved the natural characteristics of the wood.

Impregnated wood samples to both boron compound concentrations revealed no significant differences to dry density and radial shrinkage (except for clone A); tangential; radial and volumetric shrinkages; and the anisotropy coefficient for the three Eucalyptus clones.

The decrease in equilibrium moisture caused in most clones by the treatment with boron in the concentration $4 \%$ indicates a reduction of the hygroscopicity of the material, which Anjos and Sousa (2015) see as a positive effect, since this characteristic can represent greater dimensional stability. At the same time, the results presented by boron treatment at $8 \%$ also pleased the industry for the proximity of the majority of the results with the control treatment, because according to Vidal et al. (2015) and Lepage et al. (2017), one of the ideal characteristics of a wood preservative is not to change properties of the material.

The majority of the equilibrium moisture content results obtained in the acclimatization chamber were different from those arising out of the Simpson's equation (Simpson, 1971), except for the values obtained for clone $C$. The biggest difference between the two methods was $30.39 \%$ in clone $A$, in which the wood was impregnated with a $4 \%$ boron compound concentration and subjected to a temperature of $18{ }^{\circ} \mathrm{C}$ and $57 \% \mathrm{RH}$. In contrast, the lowest difference was observed for clone $\mathrm{B}$, which was $-0.33 \%$ in the control wood samples when submitted to $30^{\circ} \mathrm{C}$ and $67 \% \mathrm{RH}$.

The Simpson's equation caused significant estimation errors when assessing the moisture content of 27 commercial wood species using the acclimatization chamber (Trugilho et al., 2000). These results agree with the statement by Wallis (1970) and Jankowsky (1979) that equations utilized in the calculation of equilibrium moisture content for drying wood in the oven should not be indiscriminately used for any species as they indicate mean values and may lead to errors during wood drying.

The mean dry density values for the impregnated woods using different concentrations of boron and control compounds are shown in Table 2. The exception was clone A (8\%), which presented a difference of $0.224 \mathrm{~g} \mathrm{~cm}^{-3}$ when compared to the control, due to maximum absorption of the solution (complete saturation), indicating that boron impregnation provided a significant change in the dry density of the wood. For clones B and $C$, the maximum differences were 0.121 and $0.132 \mathrm{~g} \mathrm{~cm}^{-3}\left(121\right.$ and $\left.132 \mathrm{~kg} \mathrm{~m}^{-3}\right)$, respectively, with no significant difference in the evaluated properties.

Table 2. Mean values of the dry density $\left(\mathrm{g} \mathrm{cm}^{-3}\right)$ for the impregnated wood using different boron compound concentrations and control.

\begin{tabular}{cccc}
\hline \multirow{2}{*}{ Clone } & \multicolumn{3}{c}{ Dry density boron compound concentrations (\%) } \\
\cline { 2 - 4 } & $\mathbf{4}$ & $\mathbf{8}$ & $\mathbf{0}$ (Control) \\
\hline $\mathrm{A}$ & $0.769 \mathrm{ab}$ & $0.941 \mathrm{a}$ & $0.717 \mathrm{~b}$ \\
$\mathrm{~B}^{*}$ & $0.815 \mathrm{a}$ & $0.953 \mathrm{a}$ & $0.832 \mathrm{a}$ \\
$\mathrm{C}^{*}$ & $0.669 \mathrm{a}$ & $0.644 \mathrm{a}$ & $0.537 \mathrm{a}$ \\
\hline
\end{tabular}

Means followed by the same letter in each line, do not differ (Tukey, $p>0.05)$ or * $(F, p>0.05)$.

With the use of the higher boron compound concentration (8\%) in the solution an increase in dry density on clone A (Table 2) was verified, while the non-impregnated wood presented lower values. Increase in the density of Eucalyptus wood after impregnation with the boron compound was also observed by Baraúna et al. (2017), revealing that this affected the increase in the wood mass without changing its volume. According to Faria et al. (2015), 
the utilization of other chemical compounds, like CCA, also caused an increase in Eucalytus camaldulensis wood density. Souza Almeida et al. (2019) obtained similar results for three Brazilian tropical woods treated whit CCA-A.

Table 3 shows that for clone A wood samples, the impregnation with the highest boron compound concentration (8\%) produced greater radial shrinkage when compared to control. However, the greater radial shrinkage did not influence positively the improvement of the wood anisotropy coefficient of this clone. Despite the increase of $0.68 \%$ on the value of the radial shrinkage, there was an increase of $1.13 \%$ in the tangential one, reflecting a gain of only 0.06 in anisotropy coefficient. The values of the radial and tangential shrinkages provided an increase of $1.56 \%$ in volumetric shrinkage of clone A. The largest effect of the impregnation with boron compound to the anisotropy observed for clone C (8\%), with a difference of 0.17 for the control.

Table 3. Mean values for tangential, radial, and volumetric shrinkages and anisotropy coefficient for impregnated wood with different boron compound concentrations and control.

\begin{tabular}{|c|c|c|c|}
\hline \multirow{3}{*}{ Clone } & \multicolumn{3}{|c|}{ Boron compound concentrations (\%) } \\
\hline & 4 & 8 & 0 (Control) \\
\hline & \multicolumn{3}{|c|}{ Tangential shrinkage } \\
\hline$A^{*}$ & $6.90 \mathrm{a}$ & 7.43 a & $6.30 \mathrm{a}$ \\
\hline $\mathrm{B}^{*}$ & $5.90 \mathrm{a}$ & $6.47 \mathrm{a}$ & $5.77 \mathrm{a}$ \\
\hline \multirow[t]{2}{*}{$C^{*}$} & $6.22 \mathrm{a}$ & $6.56 \mathrm{a}$ & $5.91 \mathrm{a}$ \\
\hline & \multicolumn{3}{|c|}{ Radial shrinkage } \\
\hline$A$ & $3.25 a b$ & $3.65 \mathrm{a}$ & $2.97 \mathrm{~b}$ \\
\hline $\mathrm{B}^{*}$ & $3.14 \mathrm{a}$ & $3.52 \mathrm{a}$ & $2.93 \mathrm{a}$ \\
\hline \multirow[t]{2}{*}{$C^{*}$} & $2.95 \mathrm{a}$ & $3.39 \mathrm{a}$ & $2.79 \mathrm{a}$ \\
\hline & \multicolumn{3}{|c|}{ Volumetric shrinkage } \\
\hline$A^{*}$ & $10.01 \mathrm{a}$ & $10.88 \mathrm{a}$ & $9.32 \mathrm{a}$ \\
\hline$B^{*}$ & $8.97 \mathrm{a}$ & 9.89 a & $8.74 \mathrm{a}$ \\
\hline \multirow[t]{2}{*}{$C^{*}$} & $9.20 \mathrm{a}$ & $9.97 \mathrm{a}$ & $8.98 \mathrm{a}$ \\
\hline & \multicolumn{3}{|c|}{ Anisotropy coefficient } \\
\hline$A^{*}$ & $2.10 \mathrm{a}$ & $2.05 \mathrm{a}$ & $2.11 \mathrm{a}$ \\
\hline$B^{*}$ & $1.93 \mathrm{a}$ & 1.93 a & $1.97 \mathrm{a}$ \\
\hline$C^{*}$ & $2.14 \mathrm{a}$ & $1.96 \mathrm{a}$ & $2.13 \mathrm{a}$ \\
\hline
\end{tabular}

Means followed by same letter in each line and property, do not differ (Tukey, $p>0.05)$ or * $(F, p>0.05)$.

Boron compounds significantly influenced wood radial shrinkage in clone A (Table 3). The results show that for clone $A$ wood samples, the impregnation with the highest boron compound concentration (8\%) produced a higher radial shrinkage when compared to control, which could have been caused by increased wood density for this clone. In contrast, the lowest concentration (4\%) did not differ from the control for tangential, radial, and volumetric shrinkages and anisotropy coefficient, indicating a good performance of this treatment.

The anisotropy coefficients of the woods for the three Eucalyptus clones showed no response to the presence of the different boron compound concentrations. However, the values were relatively higher than the value of 1.87 reported by Gonçalves et al. (2009) for Eucalyptus sp. wood, and also lower than 2.34 for the Eucalyptus benthamii wood studied by Müller et al. (2014).

The inverse relationship between the anisotropy coefficient and dry density was recorded by Moraes et al. (2009) in their study on Pinus tecunumanii and Faria et al. (2015) and by Baraúna et al. (2017) using different species of Eucalyptus sp.; the present work, however, did not find this relationship. 
Similar to observed in this research with $8 \%$ boron compound concentration, Paes et al. (2015) noted that lithium chloride and copper sulphate II solutions (5\% concentration) gave the Corymbia torelliana wood smaller anisotropic coefficients. On the other hand, in Eucalyptus cloeziana wood, the lowest values were obtained with the solutions of copper sulphate and sodium chloride. This was probably caused by the bulking effect, proportionated by salt (Paes et al., 2013), keeping the cellular structure always saturated and decreased the effects of shrinkage and swelling of treated wood.

\section{CONCLUSION}

The highest boron compound concentration in the wood had no effect on the equilibrium moisture content in most relations (temperature $x$ relative humidity). However, in general, the equilibrium moisture contents revealed significantly lower values for the lowest boron compound concentration (4\%).

Care is required when employing the Simpson's equation in wood drying programs. The calculated values were different values from those measured in the acclimatization chambers.

The presence of boron compounds in the wood affected the dry density only for clone A, in which the highest concentration caused an increase in dry density and radial shrinkage.

\section{REFERENCES}

American Wood Protection Association - AWPA. (2014). AWPA E10-12: standard method of testing wood preservatives by laboratory soil-block cultures (11 p.). Birmingham: AWPA.

Anjos, F. P., \& Sousa, A. M. L. (2015). Umidade de equilíbrio em madeira termorretificada de cupiúba da região amazônica. Biota Amazônia, 5(1), 99-104. http://dx.doi.org/10.18561/21795746/biotaamazonia.v5n1p99-104.

Baraúna, E. E. P., Nunes, A. M., Moulin, J. C., Monteiro, T. C., Arantes, M. D. C., \& Paes, J. B. (2017). Influência de compostos de boro nas propriedades físicas da madeira de Eucalyptus sp. Scientia Forestalis, 45(113), 197-204. http://dx.doi.org/10.18671/scifor.v45n113.20.

Caldeira, F. (2010). Boron in wood preservation: a review in its physico-chemical aspects. Silva Lusitana, 18(2), 179-196.

Colakoglu, G., Colak, S., Aydin, I., Yildiz, U., \& Yildiz, S. (2003). Effect of boric acid treatment on mechanical properties of laminated beech veneer lumber. Silva Fennica, 37(4), 505-510. http://dx.doi.org/10.14214/sf.488.

Davidson, A. J., Binks, S. P., \& Gediga, J. (2016). Lead industry life cycle studies: environmental impact and life cycle assessment of lead battery and architectural sheet production. International Journal of Cycle Assessment, 21(11), 1624-1636. http://dx.doi.org/10.1007/s11367-015-1021-5.

Faria, W. S., Resende, D. R., Guimarães, I. L., Protásio, T. P., \& Guimarães Junior, J. B. (2015). Avaliação das propriedades físico-mecânicas da madeira de Eucalyptus cmaldulensis tratado e não tratado com preservativo. Enciclopédia Biosfera, 11(21), 287-293.

Gonçalves, F. G., Oliveira, J. T. S., Lucia, R. M. D., Nappo, M. E., \& Sartório, R. C. (2009). Densidade básica e variação dimensional de um híbrido clonal de Eucalyptus urophylla $\times$ Eucalyptus grandis. Revista Árvore, 33(2), 277-288. http://dx.doi.org/10.1590/S0100-67622009000200009.

International Organization for Standardization - ISO. (1981). ISO 4469: wood: determination of radial and tangential shrinkage. Geneva: ISO.

International Organization for Standardization - ISO. (1982). ISO 4858: wood: determination of volumetric shrinkage. Geneva: ISO.

Jankowsky, I. P. (1979). Influência da densidade básica e do teor de extrativos na umidade de equilíbrio da madeira (Dissertação de mestrado). Escola Superior de Agricultura "Luiz de Queiroz", Universidade de São Paulo, Piracicaba.

Kartal, S. N., Hwang, W., \& Imamura, Y. (2007). Water absorption of boron-treated and heat-modified wood. Journal of Wood Science, 53(5), 454-457. http://dx.doi.org/10.1007/s10086-007-0877-9.

Kartal, S. N., Yoshimura, T., \& Imamura, Y. (2004). Decay and termite resistance of boron-treated and chemically modified wood by in situ co-polymerisation of allylglycidyl ether (AGE) with methyl methacrylate (MMA). International Biodeterioration \& Biodegradation, 53(2), 111-117.

http://dx.doi.org/10.1016/j.ibiod.2003.09.004. 
Lahiry, A. K. (2005). Non-pressure treatability of plywood by CCA, CCB and boron (Doc. IRG/WP 05-40295). Stockholm: International Research Group on Wood Preservation.

Lepage, E., Salis, A. G., \& Guedes, E. C. R. (2017). Tecnologia de proteção da madeira. São Paulo: Montana Química.

Lesar, B., Kralj, P., \& Humar, M. (2009). Montan wax improves performance of boron based wood preservatives. International Biodeterioration \& Biodegradation, 63(3), 306-310. http://dx.doi.org/10.1016/j.ibiod.2008.10.006.

Lyon, F., Thevenon, M.-F., Hwang, W.-J., Imamura, Y., Gril, J., \& Pizzi, A. (2007). Effect of an oil heat treatment on the leachability and biological resistance of boric acid impregnated wood. Annals of Forest Science, 64(6), 673-678. http://dx.doi.org/10.1051/forest:2007046.

Mohareb, A., Thévenon, M. F., Wozniak, E., \& Gérardin, P. (2010). Effects of monoglycerides on leachability and efficacy of boron wood preservatives against decay and termites. International Biodeterioration \& Biodegradation, 64(2), 135-138. http://dx.doi.org/10.1016/j.ibiod.2009.12.004.

Moraes, S. P. N., Melo, J. T., Teles, R. F., \& Rodrigues, T. O. (2009). Variação axial das propriedades físicas da madeira de cinco procedências de Pinus tecunumanii no Cerrado do Distrito Federal, DF (Boletim de Pesquisa e Desenvolvimento, No. 252). Planaltina: Embrapa Cerrados.

Mourant, D., Yang, D. Q., Lu, X., Riedl, B., \& Roy, C. (2009). Copper and boron fixation in wood by pyrolytic resins. Bioresource Technology, 100(3), 1442-1449. PMid:18835155. http://dx.doi.org/10.1016/j.biortech.2008.08.021.

Müller, B. V., Rocha, M. P., Cunha, A. B., Klitzke, R. J., \& Nicoletti, M. F. (2014). Avaliação das principais propriedades físicas e mecânicas da madeira de Eucalyptus benthamii Maiden et Cambage. Floresta e Ambiente, 21(4), 535-542. http://dx.doi.org/10.1590/2179-8087.050413.

Obanda, D. N., Shupe, T. F., \& Barnes, H. M. (2008). Reducing leaching of boron-based wood preservatives - A review of research. Bioresource Technology, 99(15), 7312-7322. PMid:18295480. http://dx.doi.org/10.1016/j.biortech.2007.12.077.

Özçifçi, A. (2008). Impacts of impregnation with boron compounds on the bonding strength of wood materials. Construction \& Building Materials, 22(4), 541-545. http://dx.doi.org/10.1016/j.conbuildmat.2006.11.006.

Paes, J. B., Loiola, P. L., Oliveira, J. T. S., Braz, R. L., \& Klitzke, R. J. (2015). Efeito de soluções salinas na estabilidade dimensional das madeiras de Corymbia torelliana e Eucalyptus cloeziana. Scientia Forestalis, 43(106), 271-281.

Paes, J. B., Loiola, P. L., Euflosino, A. E. R., Salvador, F. M., \& Vitória, J. B. (2013). Efeito de soluções salinas na estabilidade dimensional da madeira de kiri (Paulownia tomentosa). Revista Científica Eletrônica de Engenharia Florestal, 21(1), 72-84.

Rosa, R. A., Paes, J. B., Segundinho, P. G. A., Vidaurre, G. B., \& Gonçalves, F. G. (2014). Efeitos do tratamento preservativo e adesivo nas características mecânicas do laminado colado de duas espécies de bambu. Scientia Forestalis, 42(103), 451-462.

Rosa, R. A., Paes, J. B., Segundinho, P. G. A., Vidaurre, G. B., \& Oliveira, A. K. F. (2016). Influências da espécie, tratamento preservativo e adesivos nas propriedades físicas do bambu laminado colado. Ciência Florestal, 26(3), 913-924. http://dx.doi.org/10.5902/1980509824220.

Simpson, W. T. (1971). Equilibrium moisture content prediction for wood. Forest Products Journal, 21(5), 48-49.

Singh, T., \& Singh, A. P. (2012). A review on natural products as wood protectant. Wood Science and Technology, 46(5), 851-870. http://dx.doi.org/10.1007/s00226-011-0448-5.

Skaar, C. (1988). Wood-water relations (Springer Series in Wood Science). Berlin: Springer-Verlag. http://dx.doi.org/10.1007/978-3-642-73683-4.

Souza Almeida, A., Criscuolo, G., Almeida, T. H., Christoforo, A. L., Chahud, E., Branco, L. A. M. N., Pinheiro, R. V., \& Rocco Lahr, F. A. (2019). Influence of CCA-A preservative on physical-mechanical properties of Brazilian tropical woods. BioResources, 14(2), 3030-3041.

Tascioglu, C., Yoshimura, T., \& Tsunoda, K. (2013). Biological decay and termite resistance of posttreated wood-based composites under protected above-ground conditions: a preliminary study after 36 months of exposure. BioResources, 8(1), 833-843. http://dx.doi.org/10.15376/biores.8.1.833843.

Torres, P. M. A., Paes, J. B., Lira Filho, J. A., \& Nascimento, J. W. B. (2011). Tratamento preservativo da madeira juvenil de Eucalyptus camaldulensis Dehnh. pelo método de substituição de seiva. Cerne, 17(2), 275-282. http://dx.doi.org/10.1590/S0104-77602011000200016. 
Trugilho, P. F., Lima, J. T., Mori, F. A., Silva, J. R. M., Mendes, L. M., \& Pinto, L. V. A. (2000). Umidade de equilíbrio da madeira para diferentes condições de temperatura e umidade relativa em câmara de climatização. Acta Amazonica, 39(1), 41. http://dx.doi.org/10.1590/S0044-59672009000100009.

Vidal, J. M., Evangelista, W. V., Silva, J. C., \& Jankowsky, I. P. (2015). Preservação de madeiras no Brasil: histórico, cenário atual e tendências. Ciência Florestal, 25(1), 257-271. http://dx.doi.org/10.5902/1980509817484.

Wallis, N. K. (1970). Australian timber handbook. Sydney: Angus and Robertson.

Willerding, A. L., \& Vianez, B. F. (2003). Utilização de bórax por difusão no tratamento de preservação de lâminas de sumaúma (Ceiba pentantra (L.) Gaertn.). Revista Árvore, 27(3), 321-326. http://dx.doi.org/10.1590/S0100-67622003000300007.

Xu, X., Lee, S., Wu, Y., \& Wu, Q. (2013). Borate-treated strand board from southern wood species: resistance against decay and mold fungi. BioResources, 8(1), 104-114. http://dx.doi.org/10.15376/biores.8.1.104-114.

Zou, C., Tang, Z., Xie, W., Fu, H., Kuang, J., Deng, Y., \& Cao, T. (2018). Effects of sodium roasting on the leaching rate of boron-bearing tailings and its mechanism analysis. Royal Society Open Science, 5(8), 172342. PMid:30224997. http://dx.doi.org/10.1098/rsos.172342.

Author's contributions: EEPB: conceptualization, data curation, investigation, methodology, supervision, project administration, JBP: supervision, conceptualization, methodology, validation, writing - review \& editing, TCM: methodology, validation, visualization, JCM: formal analysis, software, supervision, writing - review \& editing, GLF: methodology, investigation, writing - original draft, AGS: visualization, writing - review \& editing, TB: formal analysis, visualization, writing - review \& editing: CRSJr: visualization, writing - review \& editing, MDCA: validation, visualization, writing - review \& editing. 